\title{
Investigating the Joint Effects of Strategy, Environment and Control Structure on Performance
}

\author{
LindawatiGani \\ Master of Accounting and Accounting Profession Education, Faculty of Economics and Business, \\ Universitas Indonesia, Jakarta, Indonesia \\ Johnny Jermias \\ Faculty of Business Administration, Simon Fraser University, Burnaby, British Columbia
}

\begin{abstract}
The purpose of this study is to investigate the effects of misfit between competitive environment, business strategy and control structure on performance. We argue that the misfit between competitive environment, business strategy and control structure has significant negative implications on shareholder value creation associated with firms' Joint Venture formation. Based on data of publicly-traded US manufacturing firms that announce a joint venture formation, we found that firms that have perfect fit are valued higher than those with both strategy and structural misfits and also those with structural misfit. Contradictory results were found when comparing firms with perfect fit with those that have strategy misfit. Further analyses indicate that all those strategy misfit firms operate in high entry barriers, where firms can compete effectively using either innovation or cost efficiency strategy due to the fact that they possess resources that are difficult to be imitated by their competitors.
\end{abstract}

Abstrak: Penelitian ini bertujuan untuk menganalisis pengaruh dari ketidaksesuaian (misfit) antara lingkungan kompetitif, strategi bisnis dan struktur pengendalian terhadap kinerja perusahaan. Hipotesis yang diuji adalah ketidaksesuaian (misfit) antara lingkungan kompetitif, strategi bisnis dan struktur pengendalian berdampak negatif terhadap penciptaan nilai bagi pemegang saham yang berasosiasi dengan bentuk joint venture perusahaan. Berdasarkan data dari perusahaan manufaktur di AS yang mengumumkan joint venture, ditemukan bahwa perusahaan yang mempunyai kesesuaian sempurna (perfect fit) memiliki nilai yang lebih tinggi dibanding dengan yang memiliki ketidaksesuaian (misfit) strategi dan ketidaksesuaian (misfit) struktural serta yang memiliki ketidaksesuaian (misfit) struktural saja. Penelitian ini juga menemukan hasil yang bertentangan jika perusahaan dengan kesesuaian sempurna dibandingkan dengan ketidaksesuaian (misfit) strategi saja. Analisis lebih lanjut mengindikasikan perusahaan dengan ketidaksesuaian strategi beroperasi di lingkungan dengan entry barriers tinggi, yaitu kondisi pada saat perusahaan dapat berkompetisi secara efektif menggunakan strategi inovasi ataupun efisiensi biaya. Hal ini disebabkan perusahaan-perusahaan tersebut memiliki sumber daya yang sulit untuk ditiru oleh pesaing mereka.

Keywords: business strategy; contingency theory; control; environment

Corresponding authors. E-mail: lgani@ui.ac.id, and jjermias@sfu.ca

ISSN: $1141-1128$

http://www.gamaijb.mmugm.ac.id/ 
The formation of domestic as well as international joint ventures (IJVs) is typically based on the premise that the new ventures will create shareholder value for participating firms. Yet, empirical studies investigating the capital market implications of joint venture formation have reported mixed and often contradictory results. Indeed, recent surveys have documented just how pervasive and severe these inconsistencies are (Robson et al. 2002). Not only have studies failed to establish whether joint venture formation creates shareholder value for parents, there is little consistency across studies regarding the impact of individual variables on such value creation (Merchant 2000).

One reason for the mixed results seems to be the approach adopted in previous research which, usually, has investigated the singular effect of strategic and macro-economic variables on parents' shareholder value. Indeed, prior joint venture studies have seldom explicitly recognized the contingent nature of relationships among parents' competitive environment, JV strategy, JV control structure, and shareholder value (e.g., Merchant 2000; Sim and Ali 1998). This neglect is surprising because scholars in strategic management (e.g., Miller 1987) as well as other fields such as accounting (e.g., Bruns and Waterhouse 1975) have argued for the need to consider these elements simultaneously. Moreover, researchers have frequently reported that fit among firms' environment, strategy and structure has a positive effect on firm performance (e.g., Chenhall and Langfield-Smith 1988; Gupta and Govindrajan 1984; Jermias and Gani 2004; Miller 1987; Miller and Freisen 1982; Robinson and McDougall 2001; Rumelt 1974). In fact, a recent study suggested that fit among internal and external variables af- fected shareholder value creation via JVs (Merchant 2004).

This study advances the JV literature by engaging a contingency perspective to better understand the shareholder valuation effects associated with firms' JV formation. Drawing upon insights offered in the strategy and accounting literatures, this study argues that creation of shareholder value associated with JV formation depends on the (initial) fit among environment, strategy, and control structure. Moreover, the study deconstructs the notion of organizational fit (misfit) in terms of: i) strategy fit (misfit) and ii) control structure fit (misfit). It investigates the individual as well as joint effects of strategy-structure fit (misfit) on parents' shareholder value. Specifically, the study predicts that capital markets will evaluate strategy and/or structure misfits less favorably relative to the case where both these elements agree with the demands of JVs' competitive environment.

Examining the performance impact of strategy-structure misfits in the context of international JVs is important because as many as 80 percent of these ventures fail to achieve their intended objectives (Kanter 1989) and sparse explanations of such failures in the literature (Robson et al. 2002). Indeed, as Burton et al. (2002) argue, it is empirically and managerially important to investigate the impact of organizational misfits because managers react to them due to their performance implications. Thus, this study asks the following research question: Given parents' competitive environment, how do capital markets evaluate JV strategy and/or JV control structure misfits vis-à-vis "perfect fit" when international JVs are first publicly announced? 
The remainder of the paper is organized as follows. Section 2 briefly summarizes the $\mathrm{JV}$ literature pertaining to influences on shareholder value creation via JVs. Section 3 generates the study's hypotheses whereas section 4 describes its methodology. Section 5 reports the study's findings. The final section discusses these findings and highlights key implications for future research.

\section{Literature Review}

Given the popularity of JVs, numerous studies have investigated the relationship between JV formation and shareholder value creation (e.g., Gulati 1998). Although these studies have identified a wide array of influences on parents' capital market performance, most of these influences can be conveniently grouped into three categories of variables: i) environmental variables, ii) strategic variables, and iii) structural variables. In the first group belong macro variables such as cultural distance between parents' home countries, level of political risk in the JV host country, and industry conditions in parents' core business (e.g., Lummer and McConnell 1990; Madhavan and Prescott 1995; Park and Ungson 1997). In the second group belong indicators of parents' JV strategies; they include variables such as parent-venture business relatedness, type(s) of functional activity to be undertaken via JVs, and parents' JV motivations (e.g., Bleeke and Ernst 1991; Das, Sen and Sengupta 1998; Koh and Venkatraman 1991). Finally, the third group consists of structural variables such as equity distribution between partners and JV decision-making structure (e.g., Harrigan 1988; Lummer and McConnell 1990; Saxton 1997).

\section{Hypothesis Development}

As noted earlier, previous research into the relationship between above-mentioned variables and parents' shareholder value has often reported contradictory results. Recent JV studies have suggested the lack of contingency perspective as a potential reason for these conflicting findings (Merchant 2000; Sim and Ali 1998). More positively, it would be useful to move towards a study of interactions among theoretically inter-connected variables (e.g., Ginsberg and Venkatraman 1985).

Harvey (1982) argues a contingency approach to strategy research is based on the premise that an optimal strategy exists for a given set of environmental and firm-specific conditions. Likewise, Sandberg (1986) suggests that to create economic wealth for themselves, firms must align their strategies and structural variables to achieve a fit with their competitive environment. Thus, a model for testing contingent relationships among environment, strategy and structure assumes that a fit across these variables will generate better performance than will a misfit (Doty et al. 1993). Conversely, misfit across these variables will lower firm performance relative to the scenario where these elements are aligned.

Figure 1 shows the contingent relationship between environment, strategy and control structure. Cells 4 and 5 indicate the perfect fit among these three variables. Firms in Cell 4 are those operate in an environment characterized by low entry barriers, choose a strategy of efficiency, and adopt a dominant control structure. Firms in Cell 5 are those operate in an environment characterized by high entry barriers, choose a strategy of innovation, and adopt a shared control struc- 
Figure 1. The Contingent Relationship Among Environment, Strategy, and Control Structure

\begin{tabular}{|c|c|c|}
\hline & & \\
\hline & Innovation & Cost Efficiency \\
\hline & $\begin{array}{c}\text { Shared Control Structure } \\
\text { Strategy and Structural } \\
\text { Misfit (1) }\end{array}$ & $\begin{array}{l}\text { Shared Control Structure } \\
\text { Structural Misfit }\end{array}$ \\
\hline $\begin{array}{l}\text { Low Entry } \\
\text { Barriers }\end{array}$ & $\begin{array}{l}\text { Dominant Control Structure } \\
\text { Strategy Misfit (2) }\end{array}$ & $\begin{array}{c}\text { Dominant Control Structure } \\
\text { Perfect Fit (4) }\end{array}$ \\
\hline Environment & $\begin{array}{c}\text { Shared Control Structure } \\
\text { Perfect Fit (5) }\end{array}$ & $\begin{array}{l}\text { Shared Control Structure } \\
\text { Strategy Misfit (5) }\end{array}$ \\
\hline $\begin{array}{r}\text { High Entry } \\
\text { Barriers }\end{array}$ & $\begin{array}{c}\text { Dominant Control Structure } \\
\text { Structural Misfit (6) }\end{array}$ & $\begin{array}{l}\text { Dominant Control Structure } \\
\text { Strategy and Structural } \\
\text { Misfits (8) }\end{array}$ \\
\hline
\end{tabular}

ture. Cells 2 and 7 indicate the strategy misfit. Firms in cell 2 are those operate in an environment characterized by low entry barriers, choose a strategy of innovation, and adopt a dominant control structure. Firms in cell 7 are those operate in an environment characterized by high entry barriers, choose a strategy of cost efficiency, and adopt a shared control structure. Cells 3 and 6 indicate the structural misfit. Firms in Cell 3 are those operate in an environment characterized by low entry barriers, choose a strategy of efficiency, and adopt a shared control structure. Firms in Cell 6 are those operate in an environment characterized by high entry barriers, choose a strategy of innovation, and adopt a dominant control structure. Cells 1 and 8 indicate both strategy and structural misfits. Firms in cell 1 are those operate in an environment characterized by low entry barriers, choose a strategy of innovation, and adopt a shared control structure. Firms in cell 8 are those operate in an environment characterized by low entry barriers, choose a strategy of cost efficiency, and adopt a dominant control structure.

We predict that strategy and structural misfits, structural misfit alone, and strategy misfit alone, are associated with shareholder value destruction. Foster (1986) proposes that contextual variables such as competitive environment and strategic orientation of the firms should be taken into consideration when investigating the relationship between types of control and firm performance. Other researchers (e.g., Manu 1992; Douglas and Rhee 1989) speculate that an important issue in examining the relationship between 
structural/strategic variables and performance is the extent to which differences in environmental conditions influence the strategic orientation and types of control structure for optimum performance.

We adopt the environment-strategystructure paradigm proposed by Lenz, (1981) to investigate the joint effects of environment, strategy, and control structure on shareholder value at the announcement of IJV formation. This approach suggests that business environment serves as important factors in the strategy formulation (Hambrick 1982; Bourgeois 1985; Anderson and Paine 1975) and control structures are adopted to suit the firm's chosen strategy (Rumelt 1974; Channon 1973; Chandler 1962). A fit among environment, strategy and control structure will positively affect performance. This approach is based on the premise that there is no one best way to organize, and that any one way of organizing is not equally effective under all conditions (Galbraith 1973). Rather, this approach suggests that a firm should select a strategy that matches the environment in which the firm operates and the chosen strategy should be aligned with a proper control structure to positively affect performance.

\section{Strategy Misfit (Cell 2 and 7)}

The strategy misfit deals with environment and strategy relationship. The premise is that competitive environment (i.e., entry barriers) influences a firm's strategic choice. When a firm enters into joint ventures with few resources whose deployment outcomes competitors cannot duplicate (i.e., low entry barriers), current or potential competing firms can implement the same strategy but using different resources to erode the firm's sustainable competitive advantage (Dierickx and Cool 1989; Reed and DeFillippi 1990). Such erosion fundamentally stems from reduction in the level of causal ambiguity (Lippman and Rumelt 1982) surrounding the socially complex architecture of resources deployed (Dierickx and Cool 1989) by the firm. Reed and DeFillipi, (1990) argue that the reduction of ambiguity allows the competitors to observe and understand the source of competitive advantage and permit them to target their actions with the result that the erosion in the firm's sustainable competitive environment will occur at a greater rate. In such an environment, firms should plan their activity reasonably well, meet the competition, and realize efficiency (Burton et al. 2002). High performing firms in an environment characterized by low entry barriers are those who adopt a strategy of cost efficiency by focusing on aggressive construction of efficient scale facilities, vigorous pursuit of cost reduction from experience, tight cost and overhead control, avoidance of marginal customer accounts, and cost minimization in areas like research and development, service, sales force, and advertising (Porter 1985). A cost efficiency firm tries to keep its product offerings stable over time and focus on narrow product lines in order to minimize inventory carrying costs as well as to benefit from scale economies (Gupta 1987). Although these practices reduce the firms' ability to innovate and to respond to changes in competitive environment, they increase efficiency. Therefore, a cost efficiency strategy is a fit with low entry barrier environment but a misfit with high entry barrier environment.

In contrast, a firm who enters into joint ventures under high entry barriers signals a more profitable resource deployment as compared to those of incumbent and potential competitors (Bleeke and Erns 1991; Heil and Robertson 1991; Rotem and Amit 1996). The lack of that firm's sensitivity to its rivals' 
actions indicates that such firm has resources whose competitive advantage can only be minimally eroded by competitors (Richardson 1959), at least in the short-term. This would be the case when the firm possesses resources that are valuable, rare, non-imitable, non-substitutable, and non-tradable (Barney 1991; Dierickx and Cool 1989). In such an environment, firms tend to have enough resources to invest in research and development activities to increase their competitive advantage in terms of unique resources/products. High performing firms in high entry barrier environment tend to select one or more attributes that many customers in an industry perceive as important and uniquely positions themselves to meet those needs (Porter 1985). To support their strategy of producing innovative and unique products, it is essential that firms invest in research and development activities to produce new and innovative products that are superior to others in the market (Mia and Clarke 1999). Firms will then be rewarded by their ability to command premium prices and generate long term profitability (Calantone et al. 1995). In addition, innovative products can also create barriers to entry of rivals, attract new customers, and change the rules of competition in the industry (Golder and Tellis 1993). Innovative firms tend to be characterized by higher costs from innovation and are not focused on efficiency. Their ability to project into the environment with new ideas and products will sustain their competitive advantage in terms of difficultto-imitate resources and outcomes. Therefore, a strategy of innovation is a fit with an environment characterized by high entry barriers but a misfit with an environment characterized by low entry barriers.

The relationship between environment and strategy has been well studied (Miles and Snow 1978; Porter 1985; Miller 1987;
Venkatraman and Prescott 1990) and empirical findings tend to support the environmentstrategy linkage (Zahra 1996; Adler 1989; Miller 1987; Bourgeois 1985). Based on a survey of established manufacturing companies in southeastern states, Zahra (1996), for example, found that firms operate in high entry barriers tend to choose a strategy of pioneering, and radical product technologies while firms operate in a low entry barrier tend to choose a strategy of followership and incremental product and process technologies. Miller, (1987) use both published American database (called static variable) and questionnaire sent to Canadian and Australian companies (called change variable) to investigate the impact of competitive environment on the strategy formulation. He reports that the level of environmental pressure (i.e., entry barriers) was positively associated with the strategy of innovation but was negatively associated with conservative cost control strategy. Bourgeois (1985) uses a combination of interview, questionnaires and secondary data, to investigate the impact of fit between environment and strategy on firm performance. He found that congruence between environmental uncertainty and firm strategy is positively related to economic performance. That is, when the barriers to entry are low, high performing firms are those that pursue a strategy of cost efficiency whereas in an environment characterized by high entry barriers, high performing firms are associated with a strategy of innovation. Using Miles and Snow's strategic typology, Hambrick (1982) found that strategic differences between prospectors (firms that focus on innovation) and defenders (firms that focus on efficiency) occur primarily through internal analysis of the environment and political process and not through unequal possession of information. He concluded that the result 
supports the view that a firm's strategic choice depend on the environment in which the firm operates.

\section{Structural Misfit (Cell 3 and 6)}

The structural misfit deals with the relationship between control structure and strategy. The premise is that control structure should be designed in such a way to suit the chosen strategy. With its primary emphasis on cost reduction, a cost efficiency firm prefers to keep its product offerings stable overtime and have narrow product lines in order to minimize inventory carrying costs as well as to benefit from scale economies (Hambrick 1983). In addition, cost efficiency firms tend to employ routine tasks and produce standard, undifferentiated products. As such, the knowledge of means and ends is relatively high and task programmability is also high. Miles and Snow (1978) characterized the control structure of cost efficiency firms as very detailed, emphasizing on problem solving, and highly centralized. These authors also propose that control may also be achieved through creating highly specialized work roles, formalized job descriptions, and standard operating procedures. Similarly, Porter (1985) suggests that highly structured organizations are suitable for a cost efficiency focus. Govindarajan and Fisher (1990) propose that firms emphasizing on efficiency should use tight control systems to limit managers' discretionary spending and to focus management efforts on performing their tasks efficiently. Therefore, control structures that are highly centralized and formal (dominant control structure) are suitable for firms pursuing a strategy of cost efficiency because the information required to make decisions is programmable and can be formalized neglecting the possibility of overburdening the hierarchy.
Firms that pursue a strategy of innovation, by contrast, tend to pursue novel opportunities in the marketplace and require new fabrication and marketing techniques which require high involvements of managers within the firm (Miller 1987). Prior research has found that strategy of innovation is associated with high level of uncertainty (e.g., Govindarajan 1986; Lawrence and Lorsch 1967; Burns and Stalker 1961). Govindarajan (1986), for example, argues that innovative firms would face higher uncertainty due to the following reasons: first, with strong emphasis on new product developments, innovative firms will face high uncertainty since they are betting on products that have not yet crystallized.

Second, firms employing a strategy of innovation tend to have a broad set of product in order to create uniqueness. Previous researchers (e.g., Gupta 1987; Chandler 1962) have argued that product breadth is associated with high environmental complexity and consequently with uncertainty.

Finally, creating and sustaining innovation require incurring discretionary expenditures in several areas such as improvement of quality and speed of delivery, advertising to build product image, and research and development. Accordingly, implementing an innovation strategy is likely to require decisions making by intuitive judgment. Because creativity and innovativeness are crucial to differentiate themselves in the market, firms that adopt a strategy of innovation will benefit more from a control structure that promote high involvement and freedom of their managers (i.e., shared control structure) than those that adopt a low cost strategy. In addition, as uncertainty increases, information processed tend to be unstructured and more complex. As a result, more exceptions arise that must be referred upward in the hierar- 
chy which might be overloaded and serious delays develop between the upward transmission of information about new situations and a response to that information downward (Tushman and Nadler 1978). An effective way to deal with such a situation is to move the level of decision-making to where information exists rather than to bring it upward in the hierarchy, suggesting decentralization in decision-making is a proper response to increased uncertainty and to prevent from overburdening the top management with unnecessary information (Govindarajan 1986; Tushman and Nadler 1978).

Empirical research has generally supported the strategy-control structure linkage (Simons 1990; Govindarajan 1988; Miller 1987; Hambrick 1981). Miller (1987), for example, reports that centralized, formal control structure is positively related to cost efficiency strategy but negatively related to strategy of innovation. In an in-depth study of two firms using two different strategies (innovation and cost efficiency), Simons (1990), reports that the innovative firm uses more decentralized control system while the cost efficiency firm uses a more centralized control structure. Based on data from strategic business unit general managers and their superiors from 24 firms on the Fortune 500 list, Govindarajan (1988) finds that innovative firms use more decentralized control structure while cost efficiency firms use more centralized control structure. This author also reports that strategic business units employing a strategy of innovation rely more on loose control mechanisms and strategic business units employing a strategy of cost efficiency rely more on tight control system.

The preceding discussions suggest that a dominant control structure is a fit for firms pursuing a strategy of cost efficiency but a misfit for firms pursuing a strategy of innovation. In contrast, a shared control structure is a fit for firms pursuing a strategy of innovation but a misfit for firms pursuing a strategy of cost efficiency.

We predict that the degree of fit among environment, strategy and control structure will be associated with shareholder value creation while a strategy and/or structural misfit will be associated with shareholder value destruction. Specifically, the following hypotheses will be tested:

$H_{i}$ : At the announcement of IJV formation, investors will value Strategy and structural misfits (cell 1 and 8) lower than the perfect fit (cell 4 and 5)

$H_{2}$ : At the announcement of IJV formation, investors will value structural misfit (cell 3 and 6) lower than the perfect fit (cell 4 and 5).

$H_{3}$ : At the announcement of IJV formation, investor will value strategy misfit (cell 2 and 7) lower than the perfect fit (cell 4 and 5)

\section{Methodology}

\section{Sample Selection}

The sample is restricted to publiclytraded U.S. manufacturing firms that announce a joint venture formation in the Dow Jones News Retrieval Service. The manufacturing industry was selected as the research sample because firms in this industry tend to employ different types of strategy to compete effectively. In addition, firms in this industry have been facing fierce competition both domestically and internationally to capture local and world's market share (Meric et al. 2002) and therefore are expected to respond to their competitive environment by adopting a strategy and control structure that 
Table 1. Descriptive Statistics for Overall Sample

\begin{tabular}{lcccc}
\hline \multicolumn{1}{c}{ Conditions } & Mean & SD & Minimum & Maximum \\
\hline Perfect Fit $(\mathrm{n}=39)$ & 0.0034 & 0.0295 & -0.0312 & 0.0680 \\
Both Misfits $(\mathrm{n}=25)$ & -0.0096 & 0.0314 & -0.0361 & 0.0281 \\
Structural Misfit $(\mathrm{n}=34)$ & -0.0073 & 0.0236 & -0.0311 & 0.0378 \\
Strategy Misfit $(\mathrm{n}=43)$ & 0.0035 & 0.0298 & -0.0612 & 0.0483 \\
\hline
\end{tabular}

fit the environment. The use of a single industry sample also minimizes the problem of sample heterogeneity (Moores and Yuen 2001).

Data were collected from an online data source, the Dow Jones News Retrieval Service. We searched for announcements of joint venture formation between publicly-traded U.S. manufacturing firms and non-U.S. partners. To minimize the confounding effects of various economically relevant events (e.g., restructuring) on market performance measures, we follow McWilliams and Siegel's (1997) suggestion to eliminate firms who announced events other than joint venture formation during the two-day "announcement window" of interest consisting of the day a firm's joint venture participation was first publicly announced and the following day. The numbers of IJV formation announcements that meet this data requirement are 648.

To form the database for this study, additional data were collected from a variety of sources. CRSP tapes provide information about the dependent variable (abnormal returns). The Value Line Investment Surveys provide information about the environment (i.e., entry barriers). The Dow Jones News Retrieval Service also provides data about types of strat- egy, and types of control structure. These additional data requirements reduce our sample firms to 141 .

\section{Variable Measurement}

\section{Abnormal Return}

Abnormal returns are measured as the difference between stock market return associated with the announcement of the firm's participation in a JV (i.e., actual return), and the firm's historical return (i.e., normal return). Following a standard market model, the abnormal return on day $t$ for each firm $i$ is calculated as $\mathrm{AR}_{\mathrm{it}}=\mathrm{R}_{\mathrm{it}}-\left(\mathrm{a}_{\mathrm{i}}+\mathrm{b}_{\mathrm{i}} * \mathrm{R}_{\mathrm{mt}}\right)$, where $\mathrm{R}_{\mathrm{it}}=$ actual rate of return for firm $i$ on day $t$, $\mathrm{a}_{\mathrm{i}}=$ the estimated intercept for firm $i ; \mathrm{b}_{\mathrm{i}}=$ the slope of parameters for firm $i$; and $\mathrm{R}_{\mathrm{mt}}=$ rate of return on the value-weighted market portfolio on day $t$. The model was estimated over a 200-day period beginning 51 days before the announcement of JV formation. The abnormal returns are cumulated over the twoday announcement window. This aggregation is a common practice in event studies, and is done to account for capital markets reaction to announcements that may have been made after trading hours (McWilliams and Siegel 1997). 


\section{Environment}

Environment is measured based on content analyses (Webber 1990) of the descriptive information about firm-level entry barriers owned by American parents in their core business provided in Value Line Investment Surveys. This information was analyzed for indicators of firm-level entry barriers. In most cases, the tone and content of analyst reports tend to be stable, so it is relatively easy to assess the magnitude of firm-level entry barriers. In cases where the tone and content of an analyst's report were of a mixed nature, the observation was dropped from analysis. We measure entry barriers on a five-point ordinal scale $(1=$ low entry barriers to $5=$ high entry barriers). In general, this protocol fully agrees with suggestions for operationalizing resource-based concepts related to subjective measurement of entry barriers (e.g., see Godfrey and Hill 1995; Robins and Wiersema 1995; Rouse and Daellenbach 1999). Following are two examples of information used to classify the environment as high entry barriers and low entry barriers found in the Value Line Investment Surveys:

An example of 'unique resources'. "Unit shipments in the forms industry have declined... and profit margins have been squeezed significantly as a result of structural changes...[Standard Register's] forms business has been helped during this period by proprietary electronic systems..... These forms processing systems, as well as the equipment division's expertise ... should continue to enable [Standard Register's] forms segment to outpace the industry incoming years" (emphasis added).

An example of 'substitutability of resource deployment outcomes'. AT\&T has launched a new residential calling plan...We [at Value Line] see this new program as a defensive maneuver. It appears aimed at stemming the loss of residential customers to rivals MCI Communications' Friends and Family and Sprint's The Most plans" (underline added).

\section{Strategy}

This study uses Porter's (1980) strategy framework, since that conceptualization is considered by many as academically well accepted and internally consistent (Dess and Davis 1984; Hambrick 1983). Porter (1980) argues that to achieve a sustainable competitive advantage, a firm must choose either to compete on the basis of efficiency (low cost) or innovation (product differentiation). A firm's strategic orientation is determined based on information provided by the parent company regarding its motivation to form the IJVs. We only include firms that clearly indicate whether the IJV establishment is a vehicle to increase efficiency or to promote the firm's ability to innovate. Following are two examples of motivation underlying the IJV formation found in the Value Line Investment Surveys.

\begin{abstract}
An example of 'Efficiency-Seeking' STRATEGY. "The joint venture will...encompass manufacturing plants, parts distribution depots, engineering, training, and test centers and administrative offices in the U.S., Canada, and Brazil" (Source: JV formation announcement). Value Line elaborates: "The year... saw [the firm] take significant steps...including joint venture agreements in order to gain economies of scale" (emphasis added).
\end{abstract}

An example of 'INNOVATION'
STRATEGY. An example of 'resource
efficiency'. "The pricing of mature drug
products has been under pressure, due to
[America's] efforts to control healthcare
costs. Generic competition is also likely to
remain keen. Nonetheless, market penetra-
tion by newly launched products and fur-
ther product introductions....should bring about
bigher profits [for American Cyanamid].....


Cyanamid's overall product development efforts should pay off over time... [The company's] agricultural group should alsoperform well, having already gained a strong presence in many global markets" (emphasis added).

\section{Control Structure}

Control structure is determined based on information about the types of control the parent company wants to use to manage the newly created joint venture, available in the Dow Jones News Retrieval Service. This study classifies the control structure used by the parent firm to manage the IJVs into two categories: shared control structure and dominant control structure. We exclude firms that do not state clearly their intention to use a particular control structure. Following are two examples of the types of control structure use by the parent company to manage the IJV.

Example 1 of 'unilateral' decisionmaking. "Coca-Cola Amatil Ltd. of Australia and Budapesti Kiloripari Vallalat said they entered an agreement to form a joint venture company...Coca-Cola Amatil [a subsidiary] of Coca-Cola Co. will have management control." (Source: JV formation announcement; emphasis added).

Example 2 of 'unilateral' decisionmaking. "Union [a joint venture partner] will be the developer and operator of the new Dow-Sarnia storage pool, and will also administer the joint agreement." (Source: JV formation announcement; emphasis added).

Example 3 of 'unilateral' decisionmaking. "Gillette Co. said it signed a joint venture with a Soviet concern to make...razor blades, shaving systems and disposable razors... Gillette would have management control and a 65 percent equity stake in the company." (Source: JV formation announcement; emphasis added).
Example of 'shared' decision-making. "Gexa Corp. said it has reached a final joint venture agreement with Echo Bay...The venture will be directed by a management committee comprised of members from both companies." (Source: JV formation announcement; emphasis added).

\section{Statistical Analyses and Results}

Of the 141 firms, 39 firms shows perfect fit, 25 firms have both strategy and structural misfits, 34 firms have structural misfit, and 43 firms have strategy misfit. Table 2 presents the descriptive statistics and the results of the General Linear Model procedures of analyzing the effects of misfits on shareholder value. Consistent with our predictions, the mean abnormal returns for IJVs with both misfits (-0.0096) and IJVs with structural misfit (-0.0073) are lower than those of IJV's that have perfect fit $(0.0034)$. Contrary to our prediction, however, the mean abnormal returns of IJVs with strategy misfit (0.0035) are slightly higher than those of IJVs that have perfect fit (0.0034).

The overall F-statistics for the General Linear Model procedure is significant $(\mathrm{F}=$ 5.73; $\mathrm{p}<0.001)$ indicating that the fit and misfits conditions significantly affect the variation in the abnormal returns. Hypothesis $1\left(\mathrm{H}_{1}\right)$ predicts that investors will value IJVs that have both strategy and structural misfits lower than IJVs that have perfect fit. The results reveal that the abnormal returns of IJVs that have both strategy and structural misfits are significantly lower than those of IJVs that have perfect fit $(\mathrm{F}=2.38$; $\mathrm{p}<$ 0.05). ${ }^{1}$ These results confirm Hypothesis 1 $\left(\mathrm{H}_{1}\right)$. Hypothesis $2\left(\mathrm{H}_{2}\right)$ expects that inves-

${ }^{1}$ All reported $\mathrm{p}$-values are one-tailed because we are testing directional hypotheses 
Table 2. Results of the General Linear Model Procedure

\begin{tabular}{lcccc}
\hline \multicolumn{1}{c}{ Comparison } & NDF & DDF & F-value & p-Value \\
\hline Both Misfits vs. Perfect Fit & 1 & 135 & 2.38 & $<0.05^{* *}$ \\
Structural Misfit vs. Perfect Fit & 1 & 135 & 16.14 & $<0.0001^{* * *}$ \\
Strategy Misfit vs. Perfect Fit & 1 & 135 & 8.31 & $<0.001^{* * *}$ \\
\hline
\end{tabular}

*; **; ***; denote significant levels at $0.10,0.05$, and 0.01 respectively. All p-values are one-tailed since all the hypotheses are directional hypotheses.

Table 3. Descriptive Statistics for Sample Partitioned by Level of Entry Barriers

Panel A: Low Entry Barriers

\begin{tabular}{lcccc}
\hline \multicolumn{1}{c}{ Conditions } & Mean & SD & Minimum & Maximum \\
\hline Perfect Fit $(\mathrm{n}=12)$ & 0.0612 & 0.0061 & 0.0431 & 0.0680 \\
Both Misfits ( $\mathrm{n}=14)$ & -0.0193 & 0.0281 & -0.0213 & -0.0028 \\
Structural Misfit ( $\mathrm{n}=20)$ & -0.0078 & 0.0315 & -0.0375 & 0.0378 \\
& & & & \\
Panel B: High Entry Barriers & & & & \\
\hline \multicolumn{1}{c}{ Conditions } & Mean & SD & Minimum & Maximum \\
\hline Perfect Fit (n=27) & -0.0013 & 0.0191 & -0.0312 & 0.0399 \\
Both Misfits (n=11) & -0.0016 & 0.0114 & -0.0361 & 0.0281 \\
Structural Misfit (n=14) & -0.0058 & 0.0128 & -0.0311 & 0.0283 \\
Strategy Misfit (n=28) & 0.0037 & 0.0271 & -0.0612 & 0.0483 \\
\hline
\end{tabular}

tors will value IJVs that have structural misfit lower than IJVs that have perfect fit. The results show that the abnormal returns of IJVs that have structural misfit are significantly lower than those of IJVs that have perfect fit $(\mathrm{F}=16.14 ; \mathrm{p}<0.0001)$. These results are consistent with Hypothesis $2\left(\mathrm{H}_{2}\right)$. Hypothesis $3\left(\mathrm{H}_{3}\right)$ predicts that investors will value IJVs that have strategy misfit lower than IJVs that have perfect fit. The results show that the abnormal returns of IJVs that have strategy misfit is significantly higher than those of IJVs that have perfect fit $(\mathrm{F}=8.31$; $\mathrm{p}<0.001)$. These results contradict Hypothesis $3\left(\mathrm{H}_{3}\right)$. 
We conducted further analyses to investigate the contradictory results regarding $\mathrm{Hy}$ pothesis $3\left(\mathrm{H}_{3}\right)$. We partition our sample based on the two levels of entry barriers (low and high). Table 3 shows the descriptive statistics of the sample firms partitioned by the level of entry barriers.

Table 3 reveals that all the IJVs that have strategy misfit mostly operate in the high entry barriers environment. It might be that when firms possess resources that are hard to be imitated by their competitors, firms can compete effectively using either innovative or cost efficiency strategy and, therefore investors do not penalize firms that have strategy misfits when entry barriers are high and pay more attention to information about fit (misfit) when the entry barriers are low.
To investigate whether investors value fit (misfit) differently across different levels of entry barriers, we compare the abnormal returns of IJVs that have perfect fit and both strategy and structural misfits in low entry barriers with those in high entry barriers. Figure 2 illustrates the abnormal returns of the sample firms under conditions of fit (misfit) partitioned by the level of entry barriers. As shown in Figure 2, IJVs that have both strategy and structural misfits in low entry barriers are valued lower than IJVs that have strategy and structural misfits in high entry barriers (mean abnormal returns of -0.0193 and 0.0016 respectively). In addition, IJVs that have perfect fit in low entry barriers are valued higher than IJVs that have perfect fit in high entry barriers (mean abnor-

Figure 2. Environmental Effects on the Relationship between Misfits and Fit

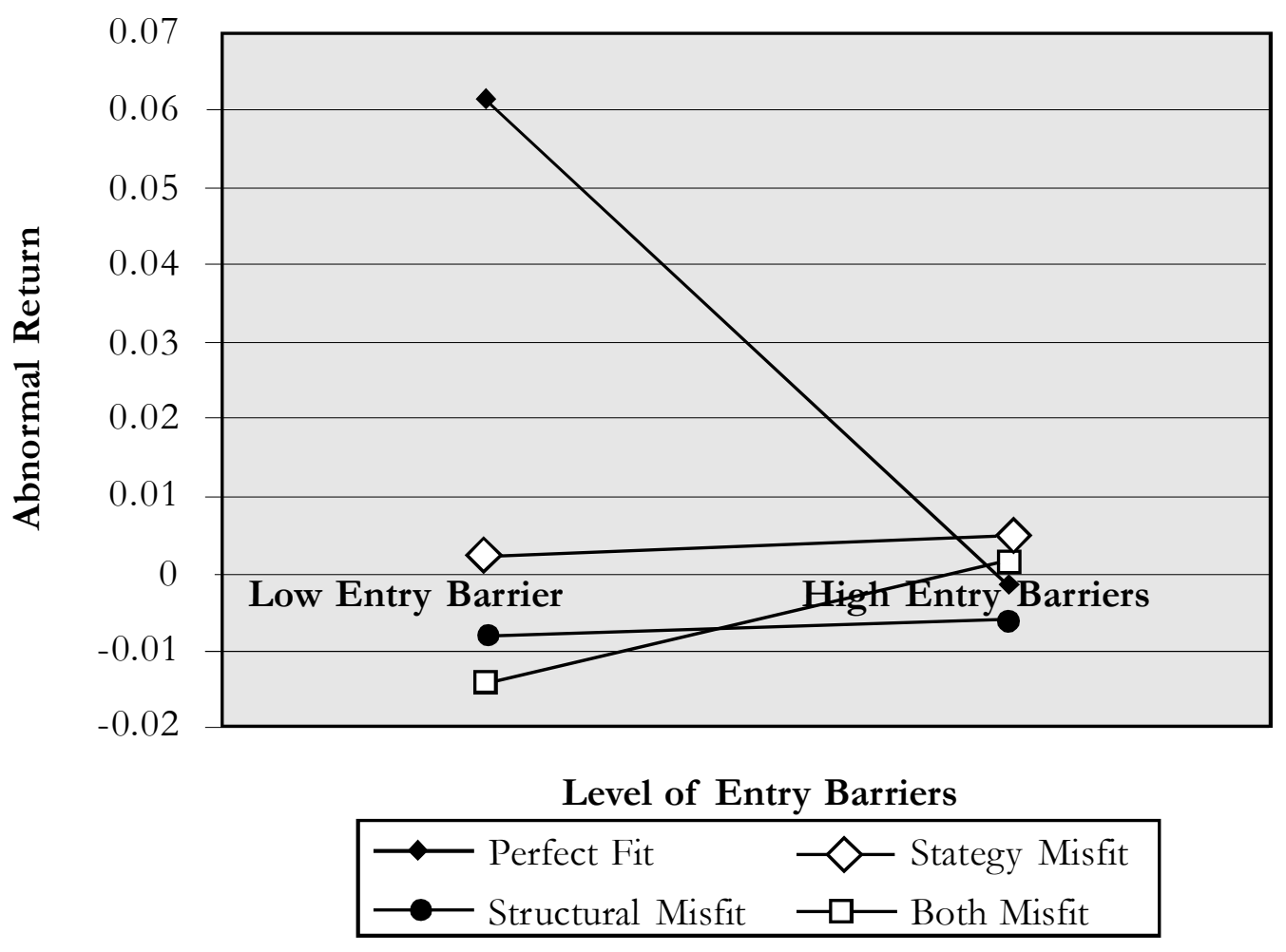


mal returns of 0.0612 and -0.0013 respectively). ${ }^{2}$ The results of these additional procedures indicate that investors pay more attention and impound the information about fit/misfits into the stock price more when the entry barriers are low as compared to when the entry barriers are high. This is not surprising because when the entry barriers are low, firms' performances are very sensitive to competitive pressure. By contrast, when the entry barriers are high, firms' performances tend to be stable due to less competitive pressure.

\section{Discussion and Direction for Future Research}

This study investigates the effects of fit (misfits) among environment, strategy, and control structure on share holder wealth on the announcement of IJVs formation. Consistent with our predictions, this study found that IJVs that have perfect fit are valued higher than those with both strategy and structural misfits and also those with structural misfit. One contradictory result was found when comparing IJVs that have perfect fit with those that have strategy misfit. While we expect that IJVs that have perfect fit will be valued higher than those with strategy misfit, the result shows the opposite. Further analyses indicate that all cases that show strategy misfit are firms that mostly operate in high entry barriers. One potential explanation for this contradictory result is that under high entry barriers, firms can compete effectively using either innovation or cost efficiency strategy due to the fact that the firms possess resources that are difficult to be imitated by their competitors. Further investigations also confirm our argument that investors tend to pay more attention to information about fit (misfit) when the entry barriers are low as compared to when the entry barriers are high.

This study makes three contributions to the literature investigating the relationship between the announcement of IJV formation and share holder value. First, we use the concept of fit among environment, strategy, and control structure and investigate the effects of fit (misfit) on share holder value creation (destruction). Although this concept is widely used in accounting and strategic management literature, it has not been tested in the context of IJVs.

Second, we deconstruct the notion of fit into strategy and structural misfits and investigate their individual and joint effects on shareholder value creation (destruction) associated with initial public announcement of IJV formation.

Third, we find that the notion of fit among environment, strategy, and control structure matters. The higher abnormal returns of IJVs that have perfect fit as compared to those with both strategy and structural misfits, and those with structural misfit is consistent with the widely held belief in the accounting and strategic management literature that the fit between environment, strategy and control structure positively affect performance.

The results of this study, however, should be interpreted in light of two limitations. First, the competitive environment used in this study is based on a subjective measure of firm-level entry barriers. It might not barriers.

${ }^{2}$ For strategy misfit and structural misfit, the results are similar for both the low entry barriers and the high entry 
necessarily reflect the true nature of competitive environment faced by the firms. Future research might consider other measures of environment such as earning volatility or types of technology.

Second, this study uses data from manufacturing sectors. Future research needs to examine whether the results reported in this study can be extended to other industries. Although the use of single industry data minimizes the sample heterogeneity problems, our understanding of the impact of fit among environment, strategy, and control structure would be enhanced if it is generalized across industries.

\section{References}

Adler, P. 1989. Technology strategy: Guide to the literature. In Rosenbloom, R. S., and R. A. Bulgelman (eds.), Research in Technological Innovation, Management and Policy. JAI Press, Greenwich, CT.

Anderson, C. R., and F. T. Paine. 1975. Managerial perceptions and strategic behavior. Academy of Management Journal 4: 811-823.

Balakrishnan, S., and M. Koza. 1993. Information asymmetry, adverse selection, and joint ventures. Journal of Economic Behavior and Organization 20: 99-117.

Barney, J. B. 1991. Firm resources and sustained competitive advantage. Journal of Management 17(1): 99120.

Bleeke, J., and D. Ernst. 1991. The way to win in cross-border alliances. Harvard Business Review 69 (6): 127135.

Bourgeois, III, L. J. 1985. Strategic goals, perceived uncertainty, and economic performance in volatile environments. Academy of Management Journal 28: 548-573.

Bruns, W. J., and J. H. Waterhouse. 1975. Budgetary control and organization structure. Journal of Accounting Research 13: 177-203.

Burns, T., and G. M. Stalker. 1961. The Management of Innovation. London: Tavistock.

Burton, R. M., J. Lauridsen, and B. Obel. 2002. Return on assets loss from situational and contingency misfits. Management Science 48 (11): 1461-1485.

Calantone, R. J., S. T. Cavusgil, and Y. Zhao. 2002. Learning orientation, firm innovation capability, and firm performance. Industrial Marketing Management 31: 515-524.

Chandler, A. D. 1962. Strategy and Structure. Cambridge, MA: MIT Press.

Channon, D. 1973. Strategy and Structure in British Enterprise. Boston, MA: Harvard University Press.

Chen, H., M. Hu, and J. Shieh. 1991. The wealth effect of international joint ventures: The case of U.S. investment in China. Financial Management 20 (4): 31-41.

Chenhall, R. H., and K. Langfield-Smith. 1988. The relationship between strategic priorities, management techniques, and management accounting: An empirical investigation using a system approach. Accounting, Organizations and Society 23: 243-264.

Crutchley, C., E. Guo, and R. Hansen. 1991. Stockholder benefits from Japanese-U.S. joint ventures. Financial Management 20 (4): 22-30. 
Dierickx, I., and K. Cool. 1989. Asset stock accumulation and the sustainability of competitive advantage. Management Science 35 (2): 1504-1511.

Doty, D. H., W. H. Glick, G. P. Huber. 1993. Fit, equifinality and organizational effectiveness: A test of two configurational theories. Academy of Management Journal 38 (6): 1198-1250.

Douglas S. P., and D. K. Rhee. 1989. Examining generic competitive strategy types in U. S. and European markets. Journal of International Business Studies 20 (3): 437-463.

Foster, R. 1986. Working the S-curve—assessing technological threats. Research Management 29 (4): 17-20.

Galbraith, J. 1973. Designing Complex Organizations. Reading, MA: Addison-Wesley.

Ginsberg, A., and N. Venkatraman. 1985. Contingency perspectives of organizational strategy: A critical review of the empirical research. Academy of Management Review 10: 421-434.

Golder, P. N., and G. J. Tellis. 1993. Pioneer advantage: Marketing logic or marketing legend? Journal of Marketing Research 30: 158-170.

Gordon, L. A., and D. Miller. 1976. A contingency framework for the design of accounting information systems. Accounting, Organizations and Society 1: 59-69.

Govindarajan, V. 1996. Decentralization, strategy and effectiveness of strategic business units in multibusiness organizations. Academy of Management Review 11: 844-856.

Govindarajan, V. 1988. A contingency approach to strategy implementation at the business-unit level: integrating administrative mechanisms with strategy. Academy of Management Journal 31 (4): 828-853.

Govindarajan, V., and J. Fisher. 1990. Strategy, control systems, and resource sharing: Effects on business unit performance. Academy of Management Journal 33: 259-285.

Gupta, A. K. 1987: SBU strategies, corporate-SBU, and SBU effectiveness in strategy implementation. Academy of Management Journal 30: 477-500.

Gupta, A. K., and V. Govindarajan. 1984. Business unit strategy, managerial characteristics, and business unit effectiveness at strategy implementation. Academy of Management Journal 27: 25-41.

Hambrick, D. C. 1981. Strategic awareness within top management team. Strategic Management Journal 2 (3): 263-279.

Hambrick, D. C. 1982. Environmental scanning and organizational strategy. Strategic Management Journal3: 159-174.

Hambrick, D. C. 1983. High profit strategies in mature capital goods industries: A contingency approach. Academy of Management Journal 26: 687-707.

Harvey, D. F. 1982. Strategic Management. Columbus, OH: Merrill.

Heil, O., and T. S. Robertson. 1991. Toward a theory of competitive market signaling: A research agenda. Strategic Management Journal 126 (6): 403-418.

Jermias, J., and L.Gani. 2004. Integrating business strategy, organizational configurations and management accounting systems with business unit effectiveness. Management Accounting Research 15 (2): 179200.

Kanter, R. M. 1989. When Giants Learn to Dance. NY: Simon and Schuster.

Koh, J., and N. Venkatraman. 1991. Joint venture formations and stock market reactions: An assessment in the information technology sector. Academy of Management Journal 34: 869-892. 
Lawrence, P. R., and J. W. Lorsch. 1967. Organization and Environment. Division of Research, Harvard Graduate School of Business Administration, Boston.

Lenz, R. T. 1981. Determinants of organizational performance: An interdisciplinary review. Strategic Management Journal 2: 131-154.

Lippman, S. A., and R. P. Rumelt. 1982. Uncertain imitability: An analysis of inter-firm differences in efficiency under competition. Bell Journal of Economics 13: 418-438.

Lummer, S., and J. J. McConnell. 1990. Stock valuation effects of international joint ventures. In Rhee, S. G., and R. P. Chang (eds.), Pacific-Basin Capital Market Research: 531-546. Amsterdam: Elsevier.

Manu, F. A. 1992. Innovation orientation, environment and performance: a comparison of U.S. and European markets. Journal of International Business Studies 23 (2): 333-351.

McConnell J. J., and T. Nantell. 1985. Corporate combinations and common stock returns: The case of joint ventures. Journal of Finance 40 (2): 519-536.

McWilliams, A., and D. Siegel. 1997. Event studies in management research: Theoretical and empirical issues. Academy of Management Journal 40 (3): 626-657.

Merchant, H., and D. Schendel. 2000. How do international joint ventures create shareholder value? Strategic Management Journal 21: 723-737.

Mia, L., and B. Clarke, B. 1999. Market competition, management accounting systems, and business unit performance. Management Accounting Research 10: 137-158.

Miles, R. E., and C. C. Snow. 1978. Organizational Strategy: Structure and Process. New York: McGraw-Hill.

Miller, D. 1987. The structural and environmental correlates of business strategy. Strategic Management Journal 8: 55-76.

Miller, D., and P. H. Friesen. 1982. Strategy making and the environment: The third link. Strategic Management Journal 4: 221-235.

Mintzberg, H. 1973. Strategy making in three modes. California Management Review 16: 44-58.

Otley, D. T. 1980. The contingency theory of management accounting: Achievement and prognosis. Accounting, Organizations and Society 5: 413-428.

Ouchi, W. 1977. The relationship between organizational structure and organizational control. Administrative Science Quarterly 22: 95-112.

Porter, M. E. 1985. Competitive Strategy. New York: Free Press.

Reed, R., and R. J. DeFillippi. 1990. Causal ambiguity, barriers to imitation, and sustainable competitive advantage. Academy of Management Review 15 (1): 88-102.

Richardson, G. B. 1959. Equilibrium, expectations, and information. Economic Journal 49: 223-237.

Robinson, K. C., and P. P. Mcdougall. 2001. Entry barriers and new venture performance: A comparison of universal and contingency approaches. Strategic Management Journal 22: 659-685.

Robson, M., L. Leonidou, and C. Katsikeas. 2002. Factors influencing international joint venture performance: Theoretical perspectives, assessment, and future directions. Management International Review 42 (4): 385-418.

Rotem, Z., and R. Amit. 1996. Competence-based strategic defense. Academy of Management Best Paper Proceedings: 56-60. 
Rumelt, R. P. 1974. Strategy, Structure, and Economic Performance. Division of Research, Graduate School of Business Administration, Harvard University, Boston.

Sakullelarasmi, P. 1991. International joint ventures: An analysis of the effects of joint venture formation on shareholder wealth. Doctoral Dissertation, University of North Texas.

Sandberg, W. R. 1986. New Venture Performance: The Role of Strategy and Industry Structure. Lexington, MA: Lexington Books.

Sharma, S., R. M. Durand, and O. Gur-Arie. 1981. Identification and analysis of moderator variables. Journal of Marketing Research XVIII: 291-300.

Tushman, M. L., and D. A. Nadler. 1978. Information processing as an integrating concept in organizational design. Academy of Management Review 3: 613-624.

Van de ven, A. H., and R. Drazin. 1985. The concept of fit in contingency theory. In Straw, B. M., and L. L. Cummings (Eds.), Research in Organizational Behavior: 333-365. JAI Press, Greenwich, CT.

Venkatraman, N., and J. E. Prescott. 1990. Environment-strategy co-alignment: An empirical test of its performance implications. Strategic Management Journal 11: 1-23.

Woolridge, J. R., and C. C. Snow. 1990. Stock market reactions to strategic investment decisions. Strategic Management Journal 11 (5): 353-363.

Zahra, S. A. 1996. Technology strategy and financial performance: examining the moderating role of firm's competitive environment. Journal of Business Venturing 11 (3): 189-219.

Zahra, S. A., and J. G. Covin. 1993. Business strategy, technology policy and firm performance. Strategic Management Journal 14: 451-478. 